\title{
Study of Blended-Learning Method Assisted By Edmodo in Teaching English at State Vocational School in Deli Serdang
}

\author{
Rini Ekayati ${ }^{1}$ \\ ${ }^{1}$ Lecturer in University of Muhammadiyah Sumatera Utara (UMSU), Medan, Indonesia \\ riniekayati@umsu.ac.id
}

\begin{abstract}
This study aims to describe blended-learning method assisted by Edmodo in teaching English at State Vocational School in Deli Serdang. Descriptive qualitative method was used in this study in order to examine factors, expected methods, and the pattern in teaching English at State Vocational School in Deli Serdang, by administrating questioner, interview, and observation as source of data taken from the sample. The research was conducted at two State Vocational Schools in Deli Serdang, namely SMK Negeri 1 Percut and SMK Negeri. The results show that there are: 1) 7 factors to be considered in selecting the teaching method for English subject, such as learning objectives, materials, resources, members of the learning process, facilities, time, and the number of study groups), 2) the expected method of teaching English in the vocational school are the student center learning method and technology-based learning method, and 3) there are 2 patterns of blended-learning learning methods assisted by Edmodo, and which are obtained based on lesson time.
\end{abstract}

Keywords : teaching method; e-learning; blended-learning model; Edmodo.

\section{Introduction}

At present time in Indonesia, English learning has started since elementary school, even in some kindergarten or PAUD, English learning has been introduced even though the portion is still very simple. In order to support the target of the learning process, careful and appropriate methods are needed in teaching English itself. In line with the development of the world of information and technology (IT) today, the method chosen must also be able to keep up with the IT development. Therefore, the success of educators in choosing the right method also supports success in achieving learning goals.

Unfortunately, the skills of English teachers now day still need to be improved and developed, especially for high vocational school and the other equivalent education units. According to the research of Kastaredja (2008), from year to year the success of learning English for high school level is still not satisfying for parents, professionals, and lecturers when students start college. This can be caused by several factors, including learning methods that are not varied or boring. Learning methods chosen by teachers tend to be conventional, there is no visible effort to innovate and create using learning methods that are more in line with the development of the current era.

This condition is much further exacerbated by the lack of effort by English teachers to use technology such as the use of laptops and the internet as supporting media in learning methods that can influence the success of the learning process itself. Even though today there are many schools that provide free internet facilities (Wi-Fi), however, these conditions have not been fully utilized by the teachers. This kind of situation also occurs in Deli Serdang State Vocational School, namely State Vocational High School 1 Percut and State Vocational School Beringin 1. Initially the blended learning method with the Edomodo application has been introduced through training activities related to e-learning method assisted with Edmodo applications in both locations. Through this activity, the teachers teaching at the school were trained to use online learning applications namely Edmodo in the learning and teaching process. (M. Arifin and Rini Ekayati: 2016). However, the blended learning method with 
Edmodo application has not been maximally applied in SMK 1 Percut and SMK 1 Beringin. This is of course very unfortunate considering the school has equipped the school with internet (Wi-Fi) facilities. Therefore, it is necessary to conduct a study of blended learning methods with Edmodo application, especially in English subjects at State Vocational School in Deli Serdang.

The learning method offered in this research is a method that is collaborated between information systems and technology (IT) through the use of internet networks through online learning application facilities with conventional learning methods (face-to-face) known as blended learning methods assisted by Edmodo. Edmodo itself is a learning platform that can be a special networking for teachers and students to share information in a virtual learning class, such as giving online tests and delivering online learning as well.

Previous studies revealed that the application of learning methods with the use of Edmodo applications in learning activities has a very significant impact. Ekayati (2017) reveals that the implementation of the blended learning method based on Edmodo application provides a positive impact where lecturers and students are actively involved in learning activities, both online and face to face. Furthermore, Ekayati (2015) revealed that Edmodo media can improve students' learning independence which is only $13.33 \%$ at pre-cycle. After the first cycle (one), the results of the increase in learning independence were $29.52 \%$, and in the second cycle the results were $79.05 \%$, and had reached the target of completeness. In addition, the level of awareness of the language of students measured by the level of language errors also showed a significant decrease in the value of errors, where in the first cycle found a $65.71 \%$ language error and $11.43 \%$ in the second cycle. This shows the difference in value decreases the error rate by $54.28 \%$. These results indicate that Edmodo application has been optimally used in improving learning independence and also awareness of student language. Thus, blended learning method assisted by Edmodo shows good benefits considering how important it is to find a learning method that can help overcome learning problems, especially learning English.

\section{Review of Literature}

\section{Teaching Method}

According to Sangidu (2004) the method is a systemic way of working to begin the implementation of an assessment activity in order to achieve a predetermined goal. Furthermore, Salamun (in Sudrajat, 2009) states that learning methods are a different way to achieve different learning outcomes under different conditions. This means that the selection of learning methods must be adapted to the conditions of learning and the learning outcomes to be achieved. In addition, based on this opinion it can be concluded that the learning method is a complete and systemic planning in presenting subject matter. Learning methods are carried out regularly and gradually in different ways to achieve certain goals under different conditions.

While self-learning is a teaching and learning activity that involves students and teachers by using various learning resources, both in class situations and outside the classroom. This is certainly not an easy job. Teachers/lecturers who act as facilitators in the learning environment must be able to accommodate the needs of students in learning activities. This condition is increasingly complicated by the development of information and communication technology today, where teachers/lecturers must be able to develop the application of technology in an integrated, systematic and effective manner. This is in accordance with the Regulation of the Minister of Education and Culture No. 652013 concerning the use of information technology 
to improve the efficiency and effectiveness of learning. Thus, learning with integrated information technology cannot be bargained to improve the quality and quality of teaching and learning.

There are a variety of learning methods including:

a. tutorial method is a method of learning that is done through a process of guidance)

b. demonstration method is a method of learning that is done by demonstrating or demonstrating processes, situations, objects, or ways of working,

c. debate method is a learning method that aims to improve the academic abilities of students,

d. role playing method is a method of learning that is carried out by mastering learning material through the development of imagination and appreciation,

e. problem solving method (Sudjana, 2005).

Along with the development of the world of information and communication technology, there has now emerged a new learning method by utilizing a computer network system with the internet. This learning method is flexible, open, and not bound by the boundaries of space and time. One special feature of this learning method is the shifting of learning patterns from conventional (face to face) to more open learning methods with the help of information and communication technology as a medium. Learning methods that combine conventional learning models with information and communication technology-based learning continue to evolve and give rise to new mixed learning models, and are known as blended-learning "mixed learning" that is combining conventional learning (only face to face) with learning using information and communication technology.

\section{Blended Learning Assisted By Edmodo Application}

Basically, blended learning method is the development of e-learning learning methods, namely a learning process through the application of internet or other computer information technology (ICT) to create innovative and efficient learning activities. Murtiyasa (2012) revealed that e-learning is learning that uses ICT to transform the learning process between educators and students. The main purpose of using this technology is to improve efficiency and effectiveness, transparency, and learning accountability, while blended learning itself is a learning method that combines e-Learning systems with conventional methods or face-to-face. (Rooney, 2003). In other words, it can be concluded that blended-learning is a combination of e-learning and traditional class systems. With this system it will accommodate elements of elearning such as simulations, virtual laboratories, and online discussions into face-to-face learning in class. Learning activities can be improved using blended-learning, including collaboration and discussion, online quizzes and assignments, online inquiry and exploration, such as individual activities such as e-journals, blogs or e-portfolios. Face-to-face activities can also be applied in a blended-learning system, such as tutorials, lab work in the laboratory and project work.

From the various definitions above, experts generally agree that blended learning places more emphasis on combining / unifying conventional learning methods (face-to-face) with elearning methods. As shown in the picture below: 


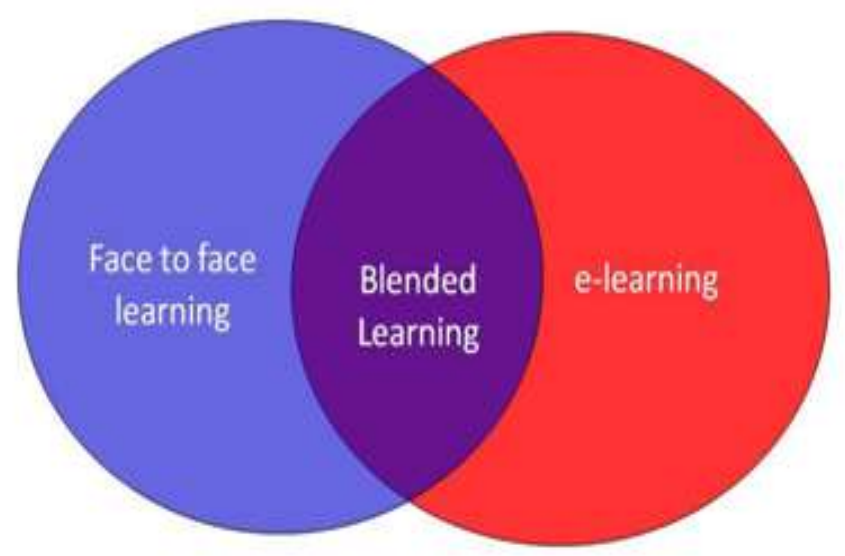

Figure 1. The Concept of Blended Learning Methods

Liz et. al in Graham (2006) in his research showed that blended-learning strategies can help bridge the distance between learners, institutions by means of interactions between learners both online and offline and increase the effectiveness of learning and teaching experiences for learners. Components and relationships in the blended learning system were developed so as to improve learner performance. In this case, the blended learning method will be carried out with the help of online learning media namely Edmodo application.

Edmodo is a social learning platform for teachers/lecturers, students and parents developed in late 2008 by Nic Borg and Jeff O 'Hara as an effort to improve the quality of technology-based learning. In Edmodo learning, teachers/lecturers are in the midst of a strong network that connects teachers/lecturers to students/lecturers to students, administrators, and parents. According to Zwang (2010), Edmodo is a social networking-based educational site in which there are various content for education. Teachers/lecturers can post learning materials, share links and videos, project assignments, and notify student grades directly. In addition, Edmodo can store and share all digital content including blogs, links, images, videos, documents and presentations. So, Edmodo is a social media that can connect teachers/lecturers with students / students in a learning group where teachers / lecturers can send some learning material, agendas, and assignments, as well as direct assessment.

Priowirjanto (2013) expressed the advantages of Edmodo when compared to other social media Learning Management Systems, namely: (1) similar to Facebook, easy to use, (2) closed group collaboration, only those who have a group code that can take classes, (3) free, accessed online, and available for smartphones, android and iphone devices, (4) does not require a server at school / campus, (5) can be accessed wherever and whenever, (6) Edmodo is always updated by the developer, (7) Edmodo can be applied in one classes, one school, between schools in one city or district, (8) Edmodo can be used for students / students, teachers / lecturers, and parents, (9) Edmodo is used to communicate using social media, learning material, and evaluation models , (10) Edmodo supports the team teaching, co-teacher, and teacher models, (11) there are notifications, (12) badge features can be used to increase student / student motivation. 


\section{English Courses in Vocational Schools}

English is one of the foreign languages studied in Indonesia which aims to enable students to communicate and require students to be able to use it actively both verbally and in writing. Apart from that, learning English also aims to be able to make students have the English communication competence. English subjects are group A subjects (required) for Secondary Education subject units. (Minister of Education and Culture Regulation No. 70 of 2013).

In the context of learning in schools, learning activities must be carried out optimally so that students are able to practice the English skills they learn. This is very dependent on the ability and skills of the teacher in designing his learning systematically and relevant to the needs and characteristics of students. This aims to provide the widest opportunity.

For each level of school education such as high school, MA, MAK, or vocational school, it has a difference in loyal treatment of the learning process. Especially for the vocational level, learning English requires different treatment from learning English at other equivalent school levels. Vocational students are learners who are prepared to have competencies in accordance with their chosen expertise program. English subjects in vocational schools are adaptive subjects, which aim to equip students with the ability to communicate English in the context of the communication materials needed for their expertise program. The objective in detail is that students are able to 1) master basic English knowledge and skills to support the achievement of expertise program competencies; and 2) applying mastery of English language skills and skills to communicate both verbally and in writing at the intermediate level. (KTSP development team, 2006).

Based on its characteristics. English has various characteristics. According to Wells (quoted by Meiyati, 2010) states that the characteristics of English can be described as follows: (1) is a tool for communicating orally and in writing; (2) communicating is understanding and disclosing information, thoughts, feelings, and developing science, technology, and culture; (3) the ability to communicate in a complete sense is the ability to speak, namely the ability to understand and / or produce oral and / or written texts that are realized in four language skills, namely listening, speaking, reading and writing.

\section{Research Method}

The method used in this study is a qualitative research method which aims to determine the factors for selecting the method of learning English at State Vocational School in Deli Serdang, knowing the expected method of learning English at State Vocational School, and knowing the patterns of blended learning methods in English subject based on Edmodo application at State Vocational School in Deli Serdang. The subjects of research and as the source of qualitative data in this study are teachers who teach English in State Vocational Schools in Deli Serdang. The teacher who was the subject of this study consisted of teachers who were civil servants and honorariums (non PNS). In collecting data, several data collection techniques were used in this study. These techniques include observation, questionnaires and interviews, and literature studies. The data validation technique used triangulation technique, namely the qualitative data verification validation technique. This technique determines the adequacy of data in accordance with the convergence of several data sources or several procedures for collecting data. In other words, transmission is a technique for checking the validity or validity of data by using something else outside of the data for checking or 
comparing the data. (Moleong, 2007). The collected data were analyzed using qualitative descriptive methods through data collection, data reduction (data reduction), data display (data display), and conclusion drawing. (Sugiyono: 2010).

\section{Discussion}

In this study, data processing was based on the results of questionnaires (12 questions, interviews (15 questions) and observations. Each instrument used in this study was intended to answer the research problems related to factors in choosing the method of learning English at State Vocational School in Deli Serdang, the expected method of learning English at State Vocational School in Deli Serdang, and the pattern of blended learning learning methods on English subjects based on Edmodo application at State Vocational School in Deli Serdang, and the form of questionnaires and interviews that are used by using Google Form facilities online. The questionnaire made consisted of questionnaires with 2 answer options (Yes/No) and questionnaires with 4 answer options (strongly agree/agree/disagree/strongly disagree). The data obtained was described qualitatively.

The identities of the respondent can be known by the characteristics they belong, such as their sex, age, and their teaching experience year. There is only 1 man and 9 women, with the age range from $20-25$ years old there were 4 respondent, from $26-30$ years old there was 1 respondent, from 31 - 35 years old there were 2 respondent, from 36 - 40 years old there were 2 respondent, and from $45-50$ years old there was 1 respondent.

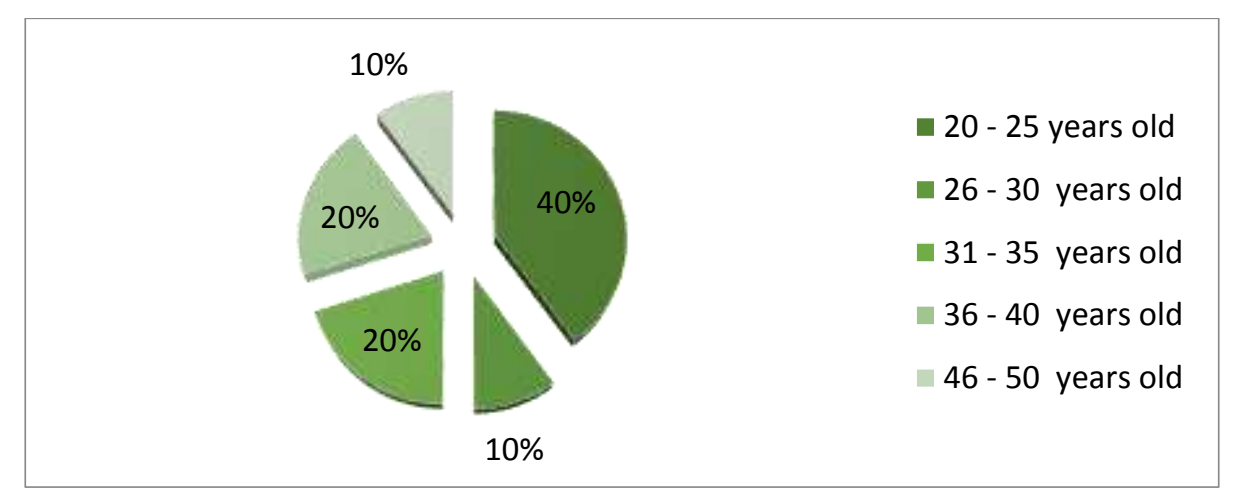

Figure 2. Distribution of Respondents by Age Group

Related to the respondents' teaching experience, the teaching period of each respondent is between 1 - 3 years amounting to 6 people (60\%), 4 - 6 years amounting to 1 person $(10 \%)$, 10 - 12 years amounting to 1 person $(10 \%), 13-15$ years is 1 person $(10 \%)$, and $16-18$ years is 1 person $(10 \%)$. 


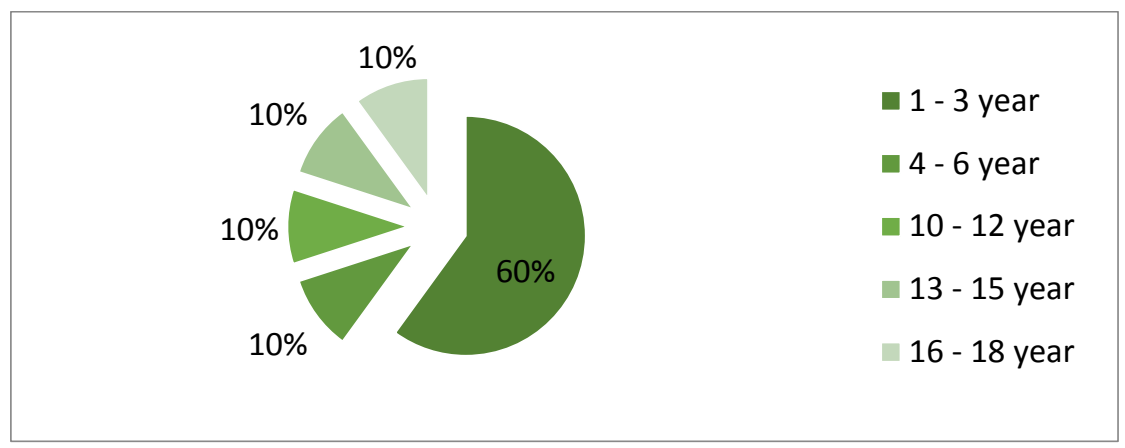

Figure 3. Distribution of Respondents by Teaching Period

Based on the respondents' answers related to the factors of choosing the English teaching method in Vocational High Schools, 7 factors were selected for the learning method, namely: learning objectives, materials, resources, members of the learning process, facilities, time, and the number of study groups. Of the seven factors, 4 (four) factors are the main factors which are the main considerations used by respondents in choosing the method of learning English in vocational schools. The four factors are learning objectives $(27.3 \%)$, learning material $(27.3 \%)$, learning facilities $(27.3 \%)$, and learning time (18.1\%).

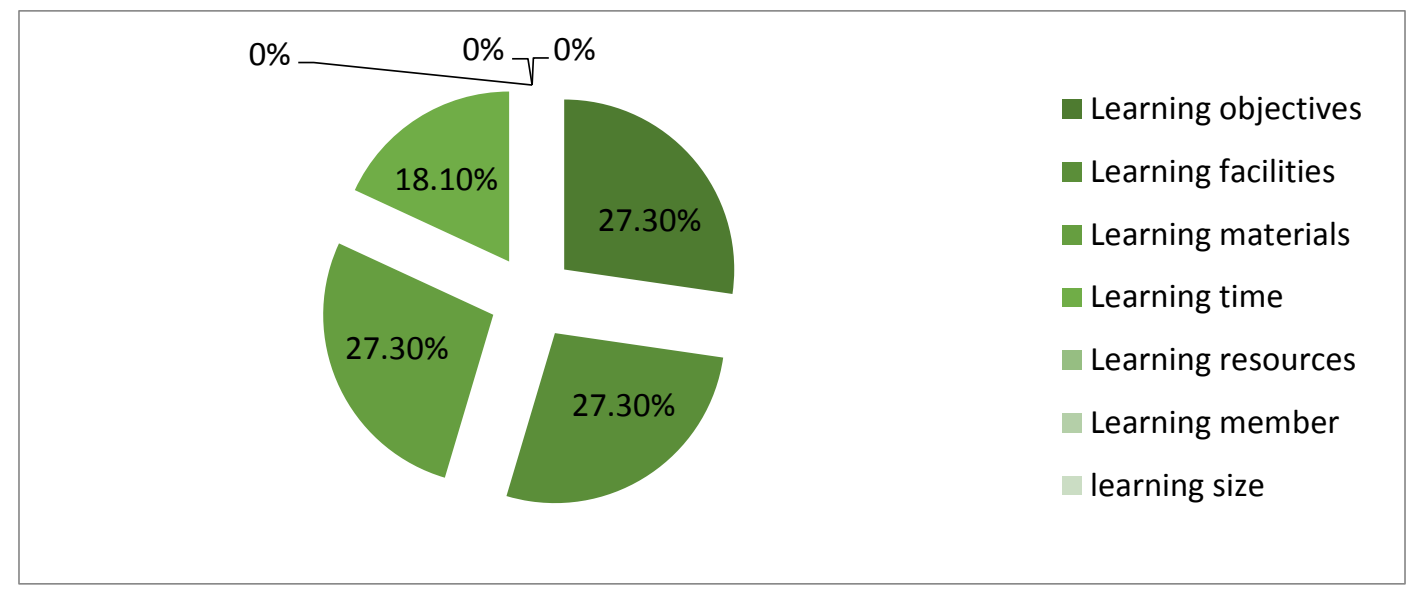

Figure 4. Distribution of Factors for Selection of English Learning Methods in Vocational Schools

Based on Figure 4 above, there are 3 factors that are not be considered in the selection of learning methods, namely learning resource, learning citizens, and the number of study groups.

The expected form of learning method is dominated by the student center learning method (4 respondents' respond (40\%)) and technology-based learning methods (6 respondents' respond $(60 \%))$. Based on the data, it can be seen that the existence of learning methods that have been centered on students and technology-based. Regarding the use of information and technology (IT) in the learning method, as many as 8 respondents $(80 \%)$ agreed that IT could be utilized in developing learning methods, and 2 respondents $(20 \%)$ responded disagreeing that IT could be utilized in developing English learning methods in SMK.

The pattern of blended-learning learning methods on English subjects based on Edmodo application at State Vocational School in Deli Serdang was then being utilized from the 
respondents' respond. Based on questionnaire and interview, all respondents have found out about blended-learning. Liz et. al in Graham (2006) in his research showed that blendedlearning strategies can help bridge the distance between learners, institutions by means of interactions between learners both online and offline and increase the effectiveness of learning and teaching experiences for learners. Blended learning methods were also used by respondents in teaching English in vocational schools where they taught with a distribution of 8 people $(80 \%)$ who had used the blended learning method, and only 2 people $(20 \%)$ had never used it.

In using the blended learning method, the pattern used based on the number of lesson hours (JP) of English course is divided based on the number of JPs available. The JP of English course in Vocational Schools is 3 JP per week. Based on the number of JPs available, and if JP provided 4 JPs in a week, respondents' responses to the pattern of application of the blended learning method were divided into 2 patterns, namely 2 JP face-to-face (2JPTM) with 2 JP online (2JPD), and $3 \mathrm{JP}$ faces advance (3JPTM) and $1 \mathrm{JP}$ online (1JPD).

Respondents (R) 1, 2, 3, 7, 9 and 10 followed the first pattern, namely 2JPTM and 2JPD. This is based on the assumption that the 50-50 JP distribution is considered a good, independent and balanced pattern. R1 said, "Blended learning is necessary, but direct delivery of material is also needed to clarify." While R2 said, "2 jp theory and 2 jp practice for certain classes is good." R3 argues, "50\% theory 50\% independent learning good." R7 said," Because when doing online it takes time to give students the material for the moment with the intended explanation on the screen that the teacher has provided, and after that face to face with students in the class asking questions about material. "Furthermore, R9 argues," To be more balanced between face-to-face learning and online and does not make students bored.", while R10 argues that learning should be balanced.

Respondents (R) 4, 5, 6, and 8 followed the second pattern, namely 3JPTM and 1JPD. This is based on the fact that face-to-face is still the main method used in learning. R4 responds that the face must be more frequent so that the teacher is more familiar with students, while R5 believes that face-to-face is enough with $3 \mathrm{JP}$, even $3 \mathrm{JP}$ face to face students feel bored, $1 \mathrm{JP}$ for online is enough because more time is given to students engrossed gaming and chattingan. "R6 states," face-to-face method is still the most important method and is followed by online methods in the learning process. "R8 argues that face-to-face is very important in learning. That is why $1 \mathrm{JP}$ is enough to do online where students can download teaching material for later reading and then be given the task to do and submit through the application provided.

From the aspects of language skills (speaking, listening, reading, and writing), Edmodo will be more used for listening skills learning, then reading, and followed by writing. With Edmodo feature that is used to communicate using social media models, learning material, and evaluation. (Priowirjanto, 2013), Edmodo allows to be used in improving students' linguistic skills. In terms of evaluation, Edmodo can be used in giving assignments to students. Because blended learning is a combination of face-to-face learning and online learning, the types of activities carried out must also be adjusted. Based on the results of interviews, the types of activities carried out at face-to-face sessions on English language subjects at Vocational Schools include tutorials, lab work, and project work. While for online sessions, it includes activities to collaborate teaching materials, assignments, online quizzes, and exploration of learning resources. With the pattern of blended-learning learning methods with Edmodo application, time efficiency in learning can be carried out well. 


\section{Conclusion}

The conclusions that can be obtained from the research are: 1) there are 7 factors to be considered for selecting learning methods (learning objectives, materials, resources, members of the learning process, facilities, time, and the number of study groups), 2) the expected method of teaching English in Vocational High School is student center learning and technology-based learning methods, and 3) there are 2 patterns of blended-learning learning methods obtained based on lesson time (JP) is 2 JP face to face (2JPTM) with 2 JP online (2JPD), and $3 \mathrm{JP}$ face to face (3JPTM) and $1 \mathrm{JP}$ online (1JPD), in terms of language skills (speaking, listening, reading, and writing) this method is more used to help problems speaking skills.

\section{References}

Arifin, M and Ekayati, Rini. 2016. I $b$ Pelatihan Mendisain Media Pembelajaran E-Learning Dengan Aplikasi Edmodo Bagi Kelompok Guru Di SMK Negeri Deli Serdang. Laporan Hasil Program Pengabdian Kepada Masyarakat.(Unpublished)

Arikunto, S. (2016). Prosedur Penelitian Suatu Pendekatan Praktik. Jakarta: Rineka Cipta.

Badan Standar Nasional Pendidikan.2006.Panduan Penyusunan Kurikulum Tingkat Satuan Pendidikan ( KTSP ) Jenjang Pendidikan Dasar dan Menengah. Jakarta: Depdiknas.

Ekayati, Rini. 2016. Optimalisasi Edmodo Dalam Meningkatkan Kemandirian Belajar dan Kesadaran Berbahasa Mahasiswa Semester VII Pada Mata Kulian LC Di Prodi Pendidikan Bahasa Inggris FKIP UMSU. Laporan Penelitian Teaching Grant, LPPM UMSU. Medan

Graham CR. 2006. Blended Learning Systems : Definition, Current Trends and Future Directions, dalam C. Bonk and C. Graham (Eds), The Hand Book of Blended Learning, Global Perspectives Local Design. San Francisco : John Wiley \& Sons, Inc., Halaman $3-19$.

Kastaredja, S. 2008. Pengembangan Bahan Ajar Bahasa Inggris. http://researchengene.com/suhartono1208.html.

Miles dan Huberman. 1994. Analisis Data Kualitatif. Jakarta; Universitas Indonesia Press.

Murtiyasa, B. 2012. Pemanfaatan Teknologi Informatika dan Komunikasi untuk meningkatkan Kualitas Pembelajaran Matematika. Surakarta: FKIP Univ. Muhammadiyah Surakarta. (on-Line) tersedia: am\%20pendidikan/TIK inEduMath.pdf.

Moleong, L. 1997. Metodologi Penelitian Kualitatif. Bandung; PT Remaja Rosdakarya.

Peraturan Menteri Pendidikan dan Kebudayaan Republik Indonesia Nomor 70 Tahun 2013

Tentang Kerangka Dasar Dan Struktur Kurikulum Sekolah Menengah Kejuruan/Madrasah Aliyah Kejuruan

Rooney, J. E. 2003, Blended learning opportunities to enhance educational programming and meetings. Association Management, 55(5), 26-32.

Sugiyono. (2015). Metode Penelitian Kuantitatif Kualitatif R\&B. Bandung: Aflabeta.

Zwang, J. 2010. Edmodo: A free, secure social networking site for schools. http://www.eschoolnews.com/2010/12/15/edmodo-a-free-secure-social-networkingsite-for-schools/, diakses 15 Oktober 2017. 